\title{
Review
}

\author{
Volume 3 - Issue 4: 165-172 / October 2020
}

\section{ONCOGENIC VIRUSES AND THEIR MOLECULAR DIAGNOSIS IN POULTRY}

\author{
Berkant Ismail YILDIZ ${ }^{1 *}$, Mustafa ERSAL ${ }^{1}$, Kemal KARABAG ${ }^{2}$
}

\author{
${ }^{1}$ Akdeniz University, Graduate School of Natural and Applied Sciences, 07058, Antalya, Turkey \\ ${ }^{2}$ Akdeniz University, Faculty of Agriculture, Department of Agricultural Biotechnology, 07058 Antalya, \\ Turkey
}

Received: March 13, 2020; Accepted: March 31, 2020; Published: October 01, 2020

\begin{abstract}
Infectious animal diseases caused by pathogenic microorganisms such as bacteria and viruses threaten the health and well-being of wildlife, livestock and human populations, limit productivity and causes significant economic losses for each. Avian oncogenic viruses are one of the most dangerous pathogenic microorganisms that threaten the poultry industry and cause damage of over billions dollars annually worldwide. These viruses include a highly contagious herpesvirus Marek's disease virus (MDV), as well as retroviruses such as avian leukosis virus (ALV) and reticuloendotheliosis virus (REV). Each group is distinguished by its nucleic acid type, antigenicity, epidemiology, host range and molecular characteristics. These viruses are cells associated with tumors and are in all organs except in the feather follicle where enveloped infectious virions egress from the body. It is difficult to detect diseases caused by these viruses and at the same time, vaccines that can provide sterile immunity against these diseases and prevent infection are incomplete. In order to be able to fight oncogenic viruses more effectively in the future, it is vital to learn more about the host immunity-oncovirus interaction and to determine powerful diagnostic techniques. In this review, oncogenic viruses and effective diagnostic techniques for these viruses are emphasized in poultry.
\end{abstract}

Keywords: Avian oncogenic viruses, Molecular diagnosis, Marek's disease virus, Avian leukosis virus, Reticuloendotheliosis virus

\author{
*Corresponding author: Akdeniz University, Graduate School of Natural and Applied Sciences, 07058, Antalya, Turkey \\ E mail: berkantyildizz@gmail.com (B.I. YILDIZ) \\ Berkant Ismail YILDIZ (iD) https://orcid.org/0000-0001-8965-6361 \\ Mustafa ERSAL (iD) https://orcid.org/0000-0002-2401-1201 \\ Kemal KARABAG (iD) https://orcid.org/0000-0002-4516-6480 \\ Cite as: Yildiz BI, Ersal M, Karabag K. 2020. Oncogenic viruses and their molecular diagnosis in poultry. BSJ Eng Sci, 3(4): 165-172.
}

\section{Introduction}

The poultry industry has great importance in providing the protein needed for human nutrition, and is the most consumed meat-poultry meat in the world, especially in OECD countries (OECD., 2014). The global population is expected to reach 9 billion by 2050 and the increased income growth among the poor population will result in an unprecedented increase in animal protein demand (King et al., 2018). In this context, attention should be given to combating infectious diseases that cause various losses in the poultry industry, which play an important role in ensuring sustainable food supply. Among these 
diseases, neoplastic diseases caused by viruses are a major economic problem facing the poultry industry worldwide (Mitra et al., 2012).

The oncogenic viruses causing neoplastic infections in chickens are herpesviruses comprising of Marek's disease virus (MDV), retroviruses comprising of reticuloendotheliosis virus (REV) and avian leukosis virus (ALV) (Davidson and Silva, 2008). The others, retrovirus and lymphoproliferative disease virus have caused significant losses from lymphomas in turkeys in the United Kingdom and Israel, but now appears to be rare (Payne and Venugopal, 2000) and it is not mentioned further in this paper.

Avian oncogenic viral lesions are often similar and it is difficult to make a differential diagnosis based on histopathology (Wang et al., 2014). In particular, the lesions caused by ALV, MDV and REV are very similar and there is no specific symptom in any of these three diseases (Gimeno et al., 2005). The laboratory assays for diagnosis are based on virus isolation, demonstration of specific antibodies and histopathological examination of tumor tissues (Mitra et al., 2012). In addition to their oncogenic property, these retroviruses are also immunosuppressive and may contaminate poultry vaccines (Biswas et al., 2011; Fadly and Witter, 1997). These contaminations have resulted in the large number of deadly infection (Fadly and Garcia, 2006; Li et al., 2013; Wei et al., 2012; Fadly et al., 1996).

\section{Avian Leukosis Virus (ALV)}

Grooming Avian leukosis virus (ALV) infection of chickens is widespread and known to be of significant economic importance; economic losses due to ALV induced tumors and reduced productivity are estimated to be in millions of U.S. dollars each year (Fadly, 2000). The term leukosis embraces several different leukaemialike proliferative diseases of the haemopoietic system caused by ALV; the term leukosis is used because a leukaemic blood picture is not always present (De Boer, 1987; Payne and Fadly, 1997).

Based on properties of viral envelope glycoproteins, ALV from chickens, a member of the leukosis/sarcoma (L/S) group of avian retroviruses are classified into six subgroups: A, B, C, D, E and J (Coffin, 1992; Payne and Fadly, 1997) and are classified as exogenous ALVs (A, B, C, D, J) and endogenous ALV (E) based on the viral envelope glycoprotein properties (Fadly, 2000). Particularly, the viral envelope glycoprotein is responsible for attachment and receptor specificity as well as the production of neutralizing antibodies (Coffin, 1992; Payne et al., 1992). Of the viral subgroups so far identified, subgroups A, B, and J are considered most prevalent and more economically important (Dai et al., 2015). Exogenous ALVs are capable of inducing lymphoid leukosis and subgroup A (ALV-A) is more commonly isolated than any other subgroup (Payne and Fadly, 1997). While exogenous ALVs have been shown to cause several neoplastic diseases in infected chickens (Cooper et al., 1968; Crittenden et al.,1980), and nonneoplastic diseases such as myocarditis (Gilka and Spencer, 1990), and osteopetrosis (Smith, 1982), ALV-E is not known to be pathogenic to chickens (Crittenden et al., 1979; Linial and Neiman, 1976). Subgroup J was first isolated in meattype chicken in the United Kingdom in 1989 but it is currently causing devastation in the poultry industry worldwide (Payne et al., 1991) and subgroup J associated primarily with myeloid leukosis in meat-type chickens (Fadly and Smith, 1999). Recent laboratory observations provided evidence for recombination between subgroup A and J ALV (ALVA/J), a recombinant ALV with the envelope of subgroup A and long terminal repeat (LTR) of subgroup J; this recombinant ALV resulted from passing ALV- J in cells expressing subgroup A envelope (Lupiani et al., 2003). As a potential contaminant of livevirus vaccines of poultry, ALV can also cause significant losses if contaminated vaccines were used in susceptible flocks (Fadly, 2016). Most recently, a recombinant subgroup A ALV containing envelope of ALV-A and LTR of ALV-E was isolated from commercial Marek's disease vaccines (Fadly et al., 2006; Silva et al., 2007). To date, because no commercial vaccines are available for control of ALV infection, eradication of virus infection at the primary breeder level remains to be the principal method for controlling ALV infection in chickens (Nair and Fadly, 2013).

\section{Marek's Disease Virus (MDV)}

Marek's disease virus (MDV), or Gallid herpesvirus 2 (GaHV-2) is the etiological agent responsible for Marek's disease (MD) in the chicken, a multifaceted disease most widely recognized by the induction of a rapid and extensive malignant T-cell lymphoma (Couteaudier and Denesvre, 2014), and MD results in substantial economic losses estimated at more than 1 billion per year (Morrow and Fehler, 2004).

Although MD was described in 1907 by Joseph Marek, the virus (MDV) was only isolated in 1967 in the United Kingdom (Churchill and Biggs, 1967) and the United States (Nazerian et al., 1968) independently. MDV is cell associated in body organs and tumors, it replicates and exists as enveloped free form in the feather follicles making feathers particularly dander, dust and litter materials loaded with MD virus, thus facilitating virus transmission by air borne route (Calnek and Witter, 1997; Adene and Akpavie, 2004; Frank, 2001). Susceptible chickens infected with the pathogenic MDV suffer cytolysis of the lymphoid organs and a concomitant immunosuppression (Gordon, 1979; Frank, 2001). Such birds mainly die as a result of tumour development in the visceral organs and peripheral nerves (Frank, 2001). Small RNA profiling studies have revealed that some viruses, particularly large DNA viruses such as Marek's disease virus (MDV) encode their own set of miRNAs (Hicks and Liu, 2013), and thus it is thought to silence the tumor suppressor genes of MDV.

The ability of MDV to replicate in the host is related to its 
pathogenicity and the MDV genome load in infected chickens contributes to our understanding of the pathogenesis of MDV infection (Baigent et al., 2005; Islam et al., 2006). In addition, several MDV encoded genes, including meq (MDV EcoRI-Q-encoded protein) (Brown et al., 2009; Lupiani et al., 2004), pp38 (MDV phosphoprotein 38) (Cui et al., 1991; Reddy et al., 2002), vIL-8 (MDV-encoded CXC chemokine viral interleukin 8) (Cui et al., 2004; Parcells et al., 2001), and ICP4 (MDV infected-cell peptide 4) (Strassheim et al., 2012; Gennart et al., 2015), play important roles in MDV pathogenesis.

Vaccination with MD vaccines is the primary approach used to protect chickens against MD (Sun et al., 2017). Although the immune-protection mechanisms induced by MD vaccines are not fully understood currently, it is recognized that effective immunity to MD requires the involvement and coordinated activation of innate and adaptive immune responses (Haq et al., 2013). Nevertheless, MD outbreaks have continued around the world in recent years, which is likely due to MDV evolution and co-infection with other viruses (WalkdenBrown et al., 2013b; Zhang et al., 2016).

\section{Reticuloendotheliosis Virus (REV)}

Reticuloendotheliosis virus (REV) is an oncogenic and immunosuppressive retrovirus that causes reticuloendotheliosis (RE) (Niewiadomska and Gifford, 2013), an avian disease mainly characterized by immunosuppression, runting-stunting syndrome and chronic lymphomas (Walker et al., 1983, Purchase et al., 1973). REV has extensive avian hosts including chickens, turkeys, ducks, mallards, geese, peafowl, pheasants, pigeons, Hungarian partridges, Chinese partridges, Attwater's prairie chickens and many other wild birds (Bohls et al., 2006; Jiang et al., 2013). REV infection of susceptible hosts such as chicks usually causes atrophy of the thymus and bursa of Fabricius, impairing the development and immune system functions of infected hosts, resulting in the suppression of host immune responses to some avian vaccines (Bulow,1977; Yang et al., 2016).

The genomic structure of REV consists of a group-specific antigen (gag), protease (pro), polymerase (pol) and envelope (env) regions flanked by long-terminal repeats (LTRs) (Witter and Fadly, 2003). The gag gene encodes five structural proteins p10, p12, pp18, pp20 and p30. The p30 (30 kDa) protein is the major REV group-specific antigen (Tsai et al.,1985). The env gene encodes two envelope glycoproteins gp90 and gp120 (Tsai et al., 1986). The pol gene encodes a reverse transcriptase similar to those of mammalian type retroviruses and differs from the Avian Leucosis- Sarcoma Virus (Moelling et al., 1975; Bauer and Termin, 1980).

The wide range of host species and potential for contaminations with REV contribute to viral transmission (Sun et al. 2017). REV can be present as a contaminant in a variety of poultry biologics and vaccines (Fadly and Garcia, 2006; Li et al., 2015) and usually REV can integrate into the genome of large DNA viruses including Marek's Disease and fowlpox (Isfort et al., 1992). Previous serological surveys have revealed that the positive rate of REV was approximately $2.3-23.5 \%$ among commercial chicken and turkey flocks in the United States (Witter et al., 1982). Usually, REV infection in chicken flocks is mainly due to REV contamination in poultry vaccines (Fadly and Garcia, 2006; Lİ et al., 2013; Wei et al., 2012; Fadly et al., 1996).

\section{Molecular Diagnosis of Oncogenic Viruses}

The frequent overlap of lesions caused by avian oncogenic virus infections requires specific laboratory diagnosis (Davidson, 2001). Nucleic acid amplification, hybridization technology and immunological tests have been adapted to diagnostic applications and identification of agents responsible for a wide variety of infectious diseases (Hafez and Hess, 1999). Different methods have been established for detecting avian oncogenic viruses, including traditional virus isolation plus an antigen-capture enzyme-linked immunosorbent assay (ELISA) for group-specific antigen of virus, immunofluorescence assay (IFA), loop-mediated isothermal amplification (LAMP) and quantitative reverse transcription PCR (Q-RT-PCR) (Kim and Brown, 2004; Zhang et al., 2010). However, each of these methods has limitations (Dai et al., 2015). For instance, ELISA and IFA are both time-consuming and quantitative data can't be acquired by the current LAMP method (Dai et al., 2015).

The PCR has become a routine technique in many research and diagnostic laboratories and real-time PCR has since its introduction in the mid-1990s removed many limitations of the standard PCR, which is significantly limited by its sensitivity (Edwards et al., 2005). In addition to enhanced sensitivity, the benefits of real-time PCR assays over conventional endpoint detection methods include their large dynamic range, a reduced risk of crosscontamination, an ability to be scaled up for highthroughput applications and the potential for accurate target quantification (Nazarenko et al., 1997; Schweiger et al., 2000; Black et al., 2002).

Zeng et al. (2015) reported the advantages of the GeXPmultiplex PCR assay to include its specificity and its highthroughput ability to immunosuppressive viruses. These advantages stem from the use of chimeric and universal primers in a 3-step PCR procedure with different annealing temperatures: the first step amplifies genespecific sequences within specific regions of the chimeric primers; the second step utilises the entire chimeric primer; and the last step uses universal primers for amplification (Zeng et al., 2015). Abdul-Careem et al. (2006) have shown that realtime PCR is 2.5-10 times more sensitive than conventional PCR techniques used for MDV detection. Moreover, PCR methods allow the detection and quantification of viral DNA in dust 
collected and concentrated on filters (Islam et al., 2006; Baigent et al., 2013; Walkden-Brown et al., 2013a).

When real-time PCR is widely used to quantify viral genes, a host gene expressed steadily in a host cells or tissue samples as an internal control becomes one pivot point for calculating the copy number of specific viral genes (Dai et al., 2015). And the sensitivity of real-time PCR assay is at least 100 times higher than that of the routine PCR assay (Dai et al., 2015). Also, it has been possible to combine several assays in a single tube with the development of multicolor real-time PCR cyclers and and "ready-to-use" commercial multiplex real-time PCR kits (Hoffmann et al., 2009). Major advantages of multiplexing include a reduced sample requirement, which is especially important when sample material is scarce (Persson et al., 2005; Belak, 2007), and the ability to combine assays with an internal control system (Hoffmann et al., 2006).

\section{Detection formats with Real Time PCR}

\subsection{Detection Formats without Sequence} Confirmation of the PCR Product

Fluorescent dyes such as ethidium bromide (Higuchi et al., 1993; Wittwer et al., 1997a; Le Pecq and Paoletti, 1966) that are specific for double-stranded DNA (dsDNA) were the first systems employed in real-time PCR assays. Other intercalating dyes such as YO-PRO-1 have also been used (Ishiguro et al., 1995; Tseng et al., 1997). SYBR Green I is currently the most frequently used intercalating dye in real-time PCR and it has a 100 times higher binding affinity than ethidium bromide and the fluorescence of bound dye is more than 1000-fold higher than that of free dye (Hoffmann et al., 2006).

These properties make SYBR Green I highly suitable for monitoring product accumulation during PCR (Wittwer et al., 1997b; Morrison et al., 1998). Another detection technology known as 'LUX (Light Upon eXtension)' utilizes a modification to one of the two primers such that it possesses a fluorophore located near the 3'end in a hairpin structure (Nazarenko, 2006; Kusser, 2006). The Amplifluor Quantitative PCR detection system uses a similar approach with labelled and unlabelled primers (Nazarenko et al., 1997; Nuovo et al., 1999; Khripin, 2006).

\subsection{Detection Formats with Increased Target Specificity}

Fluorophorelabelled oligonucleotide probes are most commonly used for the specific detection of target sequences (Cardullo et al., 1988; Clegg, 1995; Wu and Brand, 1994). In these assays, an increase in fluorescence signal proportional to the accumulation of PCR product arises as a consequence of fluorescence resonance energy transfer (FRET) between separate fluorogenic labels (known as the reporter and quencher) conjugated to the probe (or primers). FRET, also called Förster transfer, is a spectroscopic process by which energy is passed over a maximum distance of $70 \mathrm{~A}^{\circ}$ between reporter and acceptor molecules possessing overlapping emission and absorption spectra (Selvin and Hearst, 1994). The most commonly used fluorogenic quenchers are TAMRA and DABCYL, while Black Hole Quencher (BHQ) is also widely used and disperses energy from the reporter as heat rather than fluorescence (Didenko, 2001).

\subsection{Hybridisation Probes}

Hybridisation probes, also known as 'HybProbes', use a pair of adjacent, fluorogenic hybridisation oligos and are the only detection format that directlymeasures FRET (Cardullo et al., 1988). These probes have become the preferred chemistry of the manufacturer for the capillary-based LightCycler system (Wittwer et al., $1997 a, b)$ with special filters for the detection of the acceptor fluorophores Red 640 and Red 705.

\subsection{Hydrolysis Probes (50-exonuclease Assay)}

Hydrolysis probes (commercially called TaqMan1 probes) are dual-fluorophore-labelled oligonucleotides, with a 50-terminal reporter (e.g. FAM) and a 30-terminal quencher (e.g. TAMRA). (Hoffmann et al., 2009). Once the labels are separated by destroying the TaqMan1 probe based on the 50-exonuclease activity of the DNA polymerase (e.g. Taq polymerase), the increase in reporter fluorescence caused by the removal of the adjacent quencher is monitored by a realtime PCR instrument. (Heid et al., 1996; Livak et al., 1995; Gibson et al., 1996). A modification of this strategy exploits the so-called minor groove binding (MGB) probes. MGB probes form extremely stable duplexes with singlestranded DNA targets mediated via van der Waals forces (Afonina et al., 2002): as a consequence shorterlength probes are required for hybridisation. In comparison with unmodified DNA, MGB probes have higher Tm and are reported to hybridize with greater sequence specificity (Afonina et al., 1996; Kutyavin et al., 2000). These short MGB probes are ideal for allele discrimination studies or for detection of singlenucleotide polymorphisms (SNPs) because they are more significantly destabilised by nucleotide changes within the hybridisation site compared with probes of longer length (De Kok et al., 2002; Belousov et al., 2004; Itabashi et al., 2004).

\subsection{Molecular Beacons}

Molecular beacons are hairpin-shaped oligoprobes terminally labelled with a reporter and a quencher fluorophore (Tyagi and Kramer, 1996; Tyagi et al., 1998; Vet et al., 2002).

\subsection{Scorpion Primer}

The Scorpion technology is mainly used in allelic discrimination (Whitcombe et al., 1999; Thelwell et al., 2000) and in SNP genotyping (Roberts, 2000).

\subsection{Locked Nucleic Acid (LNA) Probes}

Incorporation of LNA residues increases the Tm of the oligonucleotide sequence, allowing the use of markedly shorter probes as allele-specific tools in genotyping assays (Costa et al., 2004; Latorra et al., 2003; Braasch and Corey, 2001). 


\section{Conclusion}

This study is primarily concerned with avian oncogenic viruses, the economically most important viruses such as MDV, ALV and REV. And more focused on some of the molecular techniques most commonly used to improve avian oncogenic virus detection for diagnosis and disease control. We showed some advanced biotechnological approaches that allow early detection of pathogens that affect poultry. Conventional diagnostic techniques are frequently time consuming, labor intensive and require to be performed on sophisticated equipment. Real Time PCR is one of the most important of these biotechnological methods. The high sensitivity and ability to quantify viral targets, the substantial gain in specificity and the reduced risk of cross-contamination are important features of this technology. Also, applications of Real-Time PCR include measurements of viral load, gene expression studies, clinical diagnostics and various pathogen detection.

Since it is suitable for the diagnosis of multiple viral infections, molecular techniques such as PCR and/or Real Time PCR are used for the diagnosis of avian oncogenic viruses (Silva et al., 2007). Nevertheless virus isolation is considered the "gold standard" for diagnosis and is often the starting point for more detailed studies (Nair, 2013). Virus-specific amplifications are confirmed by sequencing of precipitated PCR products. Using molecular methods can be useful for the rapid differential diagnosis of avian oncogenic viruses and for the detection of multiple infections (Gopal et al., 2012). Likewise, multiplex PCR primers can be useful in detecting the presence of ALV-J by modification in ALV primer sequences (Gopal et al., 2012). PCR has emerged as a chosen method for rapid and accurate diagnosis of viruses that appear in poultry. Multiplex PCR primers specific to MDV, ALV, REV and chicken DNA can be designed for rapid differential diagnosis (Gopal et al., 2012). Preferred amplification frequently occurs in multiplex PCR as a result of the various efficiencies of different primer pairs and due to the layout of the primer dimers. This is more likely as the number of primers increases (Elnifro et al., 2000), and the problem of amplification failure disappears when the template DNA contains several copies. This problem can be solved by optimizing multiplex PCR by changing the primer sequences, concentrations and cycle conditions (Frumkin et al., 2008).

\section{Conflict of interest}

The authors declare that there is no conflict of interest.

\section{Acknowledgements}

This article was presented as an oral presentation at the International Congress on Domestic Animal Breeding Genetics and Husbandry (ICABGEH-2019) held on 11-13 September 2019 in Prague.

\section{References}

Abdul-Careem MF, Hunter BD, Nagy E, Read LR, Sanel B, Spencer IL, Sharif S. 2006. Development of a real- time PCR assay using SYBR green chemistry for monitoring Marek's disease virus genome load in feather tips. J Virol Methods, 133: 34-40.

Adene DF, Akpavie So. 2004. An overview of Marek's disease and the options in its control, Poultry Health and Production Principles and Practices. Stering Horden Publishers Nig. LTD. Ibadan, Nigeria. pp. 107-127.

Afonina IA, Kutyavin I, Lukhtanov E, Meyer RB, Gamper H. 1996. Sequence-specific arrest of primer extension on singlestranded DNA by an oligonucleotide-minor groove binder conjugate. Proc Natl Acad Sci, 93(8): 3199-3204.

Afonina IA, Reed MW, Lusby E, Shishkina IG, Belousov YS. 2002. Minor groove binder-conjugated DNA probes for quantitative DNA detection by hybridization-triggered fluorescence. Biotechniques 32(4): 946-949, 940-944.

Baigent SJ, Kgosana L, Gamawa A, Smith LP, Read AF, Nair V. 2013. Relationship between levels of very virulent MDV in Poultry dust and in feather tips from vaccinated chickens. Avian Dis, 57:440-447.

Baigent SJ, Petherbridge LJ, Howes K, Smith LP, Currie RJ, Nair VK. 2005. Absolute quantitation of Marek's disease virus genome copy number in chicken feather and lymphocyte samples using real-time PCR. J Virol Methods, 123: 53-64.

Bauer G, Temin HM. 1980. Specific antigenic relationships between the RNA-dependent DNA polymerases of avian reticuloendotheliosis viruses and mammalian type $\mathrm{C}$ retroviruses. J Virol, 34(1): 168-177.

Belak S, 2007. Molecular diagnosis of viral diseases, present trends and future aspects. A view from the OIE Collaborating Centre for the Application of Polymerase Chain Reaction Methods for Diagnosis of Viral Diseases in Veterinary Medicine. Vaccine, 25: 5444-5452.

Belousov YS, Welch RA, Sanders S, Mills A, Kulchenko A, Dempcy R, Afonina IA, Walburger DK, Glaser CL, Yadavalli S, Vermeulen NM, Mahoney W. 2004. Single nucleotide polymorphism genotyping by two colour melting curve analysis using the MGB Eclipse Probe System in challenging sequence environment. Hum Genomics, 1(3): 209-217.

Biswas S.K, Jana C, Chand K, Rehman W, Mondal B. 2011. Detection of fowl poxvirus integrated with reticuloendotheliosis virus sequences from an outbreak in backyard chickens in India. Veterinary Italy, 47: 147-153.

Black EM, Lowings JP, Smith J, Heaton PR, McElhinney LM. 2002. A rapid RT-PCR method to differentiate six established genotypes of rabies and rabies-related viruses using TaqMan1 technology. J Virol Methods, 105(1): 25-35.

Bohls RL, Linares JA, Gross SL, Ferro PJ, Silvy NJ, Collisson EW. 2006. Phylogenetic analyses indicate little variation among reticuloendotheliosis viruses infecting avian species, including the endangered attwater's prairie chicken. Virus Res, 119: 187-194.

Braasch DA, Corey DR. 2001. Locked nucleic acid (LNA), finetuning the recognition of DNA and RNA. Chem Biol, 8(1): 1-7.

Brown AC, Smith LP, Kgosana L, Baigent SJ, Nair V, Allday MJ. 2009. Homodimerization of the Meq viral oncoprotein is necessary for induction of t-cell lymphoma by Marek's disease virus. J Virol, 83: 11142-11151.

Bulow VV. 1977. Immunological effects of reticuloendotheliosis virus as potential contaminant of Marek's disease Vaccines, Avian Pathol, 6(4): 383-393.

Calnek BW, Witter RL. 1997. Marek's disease. Diseases of Poultry, 9th ed. Iowa State University Press, Iowa. pp. 356430. 
Cardullo RA, Agrawal S, Flores C, Zamecnik PC, Wolf DE. 1988. Detection of nucleic acid hybridization by nonradiative fluorescence resonance energy transfer. Proc Natl Acad Sci, 85(23): 8790-8794.

Churchill AE, Biggs PM. 1967. Agent of Marek's disease in tissue culture. Nature, 215: 528-530.

Clegg RM. 1995. Fluorescence resonance energy transfer. Curr Opin Biotechnol, 6(1): 103-110.

Coffin JM. 1992. Structure and Classification of Retroviruses, In J. A. Levy, (Ed), The Retroviridae, vol. 1 (pp. 19- 49). New York: Plenum Press.

Cooper MD, Payne LN, Dent, PB, Burmester BR, Good RA. 1968. Pathogenesis of avian lymphoid leukosis. I. Histogenesis. J Natl Cancer I, 41(2):373-389.

Costa JM, Ernault P, Olivi M, Gaillon T, Arar K. 2004. Chimeric LNA/ DNA probes as a detection system for real-time PCR, Clin. Biochem., 37: 930-932.

Couteaudier M, Denesvre C. 2014. Marek's disease virus and skin interactions. Vet Res, 45(1): 1-12.

Crittenden LB, Hayward WS, Hanafusa H, Fadly AM. 1980. Induction of neoplasms by subgroup $\mathrm{E}$ recombinant of exogenous and endogenous avian retroviruses (Rousassociated virus type 60). J Virol, 33: 915-919.

Crittenden LB, Witter RL, Fadly AM. 1979. Low incidence of lymphoid tumors in chickens continuously producing endogenous virus. Avian Dis, 23: 646-653.

Cui XP, Lee LF, Reed WM, Kung HJ, Reddy SM. 2004. Marek's disease virus-encoded vIL-8 gene is involved in early cytolytic infection but dispensable for establishment of latency. J Virol, 78: 4753-4760.

Cui ZZ, Lee LF, Liu JL, Kung HJ. 1991. Structural analysis and transcriptional mapping of the Marek's disease virus gene encoding pp38, an antigen associated with transformed cells. J Virol, 65: 6509-6515.

Dai M, Feng M, Liu D, Cao W, Liao M. 2015. Development and application of SYBR Green i real-time PCR assay for the separate detection of subgroup J Avian leukosis virus and multiplex detection of avian leukosis virus subgroups A and B. Virol J, 12(1): 52.

Davidson I. 2001. Differential diagnosis of avian oncogenic viruses. http: //www.poultrymed.com. Accessed 6 October 2009.

Davidson I, Silva RF. 2008. Creation of Diversity in Animal Virus World by Inter Species and Intra- Species Recombinations: lessons Learned From Poultry Viruses. Virus Genes, 36: 1-9.

De Boer GF. 1987. Avian leukosis. Martinus Nijhoff Publishing, Boston, $292 \mathrm{pp}$.

De Kok JB, Wiegerinck ET, Giesendorf BA, Swinkels DW. 2002. Rapid genotyping of single nucleotide polymorphisms using novel minor groove binding DNA oligonucleotides (MGB probes). Hum Mutat, 19(5): 554-559.

Didenko VV. 2001. DNA probes using fluorescence resonance energy transfer (FRET): designs and applications. Biotechniques, 31: 1106-1121.

Edwards K, Logan J, Saunders N. 2005. Real-time PCR: an essential guide. Food Microbiol, 22: 267-268.

Elnifro EM, Ashshi AM, Cooper RJ, Klapper PE. 2000. Multiplex PCR: optimization and application in diagnostic virology. Clin Microbiol Rev, 13: 559 -570.

Fadly AM. 2000. Isolation and identification of avian leukosis viruses: a review. Avian Pathology, 29(6): 529 - 535.

Fadly AM. 2016. L53 Diagnosis and control of avian tumor viruses in poultry: a review. The Proceedings of XXV World's Poultry Congress, 5-9 September 2016, Beijing/China.

Fadly AM, Garcia MC. 2006. Detection of reticuloendotheliosis virus in live virus vaccines of poultry. Dev Biol (Basel), 126: 301-305.

Fadly AM, Silva R, Hunt H, Pandiri A, Davis C. 2006. Isolation and characterization of an adventitious avian leukosis virus isolated from commercial Marek's disease vaccines. Avian Dis, 50: 380-385.

Fadly A.M, Smith EJ. 1999. Isolation and some characteristics of an isolate asso-ciated with myeloid leukosis in meat-type chickens in the United States. Avian Dis, 43: 391-400.

Fadly AM, Witter RL. 1997. Comparative evaluation of in vitro and in vivo assays for the detection of reticuloendotheliosis virus as a contaminant in a live vaccine of poultry. Avian Dis, 41: 695-701.

Fadly AM, Witter RL, Smith EJ, Silva RF, Reed WM, Hoerr FJ, Putnam MR. 1996. An outbreak of lymphomas in commercial broiler breeder chickens vaccinated with a fowlpox vaccine contaminated with reticuloendotheliosis virus. Avian Pathol, 25: 35-47.

Frank F. 2001. Marek's disease: History, actual and future Perspectives. Lohmann Inform, No. 25, pp. 1-5.

Frumkin D, Wasserstrom A, Itzkovitz S, Harmelin A, Rechavi G, Shapiro E. 2008. Amplification of multiple genomic loci from single cells isolated by laser micro-dissection of tissues. BMC Biotechnol, 8(1): 17.

Gennart I, Coupeau D, Pejakovic S, Laurent S, Rasschaert D, Muylkens B. 2015. Marek's disease: Genetic regulation of gallid herpesvirus 2 infection and latency. Vet J, 205: 339-348.

Gibson UE, Heid CA, Williams PM. 1996. A novel method for real time quantitative RT-PCR. Genome Res, 6(10): 995-1001.

Gilka F, Spencer JL. 1990. Chronic myocarditis and circulatory syndrome in a White Leghorn strain induced by avian leukosis virus: light and electron microscope study. Avian Dis, 34: 174184.

Gimeno IM, Witter RL, Fadly AM, Silva RF. 2005. Novel criteria for the diagnosis of Marek's disease virus-induced lymphomas. Avian Pathology, 34(4): 332-340.

Gopal S, Manoharan P, Kathaperumal K, Chidambaram B, Divya KC. 2012. Differential detection of avian oncogenic viruses in poultry layer farms and turkeys by use of multiplex PCR. J Clin Microbiol, 50(8): 2668-2673.

Gordon RF. 1979. Poultry disease. Bulliere Tindall, London. 2:80. Hafez HM, Hess M. 1999. Modern techniques in diagnosis of poultry diseases: Review. Arch Geflugelkd, 63(6): 237-245.

Haq K, Schat KA, Sharif S. 2013. Immunity to Marek's disease: Where are we now? Dev Comp Immunol, 41: 439-446.

Heid CA, Stevens J, Livak KJ, Williams PM. 1996. Real time quantitative PCR. Genome Res, 6(10): 986-994.

Hicks JA, Liu HC. 2013. Current State of Marek's Disease Virus MicroRNA Research. Avian Dis, 57: 332- 339.

Higuchi R, Fockler C, Dollinger G, Watson R. 1993. Kinetic PCR analysis: real-time monitoring of DNA amplification reactions. Nat Biotechnol, 11(9): 1026-1030.

Hoffmann B, Beer M, Reid SM, Mertens P, Oura, CAL, Rijn PAV, Slomka MJ, Banks J, Brown IH, Alexander DJ, King DP. 2009. A review of RT-PCR technologies used in veterinary virology and disease control: Sensitive and specific diagnosis of five livestock diseases notifiable to the World Organisation for Animal Health. Vet Microbiol, 139: 1-23.

Hoffmann B, Depner K, Schirrmeier H, Beer M. 2006. A universal heterologous internal control system for duplex real-time RTPCR assays used in a detection system for pestiviruses. J Virol Methods, 136(1-2): 200-209.

Isfort R, Jones D, Kost R, Witter R, Kung HJ. 1992. Retrovirus insertion into herpesvirus in vitro and in vivo. Proc Natl Acad Sci, 89(3): 991-995. 
Ishiguro T, Saitoh J, Yawata H, Yamagishi H, Iwasaki S, Mitoma Y, 1995. Homogeneous quantitative assay of hepatitis C virus RNA by polymerase chain reaction in the presence of a fluorescent intercalater. Anal Biochem, 229(2): 207-213.

Islam A, Cheetham BF, Mahony TJ, Young PL, Walkden-Brown SW. 2006. Absolute quantification of Marek's disease virus and herpesvirus of turkeys in chicken lymohocyte, feather tip and dust samples using real-time PCR. J Virol Methods, 132: 127134.

Itabashi T, Maesawa C, Uchiyama M, Higuchi T, Masuda T. 2004. Quantitative detection of mutant alleles of the K-ras gene with minor groove binder-conjugated fluorogenic DNA probes. Int J Oncol, 24(3): 687-696.

Jiang L, Qi X, Gao Y, Hua Y, Li K, Deng X, Wang Q, Zhang L, Chai H, Chen Y, Yin C, Gao H, Qin L, Wang Y, Qu Y, Chen Q, Fan Z, Wang X. 2013. Molecular characterization and phylogenetic analysis of the reticuloendotheliosis virus isolated from wild birds in Northeast China. Vet Microbiol, 166: 68-75.

Khripin Y. 2006. High-throughput genotyping with energy transferlabeled primers. Methods Mol Biol, 335: 215-240.

Kim Y, Brown TP. 2004. Development of quantitative competitive-reverse transcriptase-polymerase chain reaction for detection and quantitation of avian leukosis virus subgroup J. Vet Diagn Invest, 16: 191-1966.

King T, Osmond-McLeod MJ, Duffy LL. 2018. Nanotechnology in the food sector and potential applications for the poultry industry. Trends Food Sci Technol, 72: 62-73.

Kusser W. 2006. Use of self-quenched, fluorogenic LUX primers for gene expression profiling. Methods Mol Biol, 335: 115133.

Kutyavin IV, Afonina IA, Mills A, Gorn VV, Lukhtanov EA, Belousov ES, Singer MJ, Walburger DK, Lokhov SG, Gall AA, Dempcy R, Reed MW, Meyer RB, Hedgpeth J. 2000. 30-minor groove binder- DNA probes increase sequence specificity at PCR extension temperatures. Nucleic Acids Res, 28(2): 655661.

Latorra D, Arar K, Hurley JM. 2003. Design considerations and effects of LNA in PCR primers. Mol Cell Probes, 17(5): 253259.

Le Pecq J, Paoletti C. 1966. A new fluorometric method for RNA and DNA determination. Anal Biochem, 17: 100-107.

Li J, Dong X, Yang C, Li Q, Cui Z, Chang S, Zhao P, Yu K, Yang H. 2015. Isolation, identification, and whole genome sequencing of reticuloendotheliosis virus from a vaccine against Marek's disease. Poult Sci, 94: 643-649.

Li J, Yang C, Li Q, Li H, Xia Y, Liu D, Yu K, Yang H. 2013. Complete genome sequence of reticuloendotheliosis virus strain MD-2, isolated from a contaminated turkey herpesvirus vaccine. Genome Announc, 1, e00785-13.

Linial M, Neiman PE. 1976. Infection of chicken cells by subgroup E viruses. Virology, 73: 508520.

Livak KJ, Flood SJ, Marmaro J, Giusti W, Deetz K. 1995. Oligonucleotides with fluorescent dyes at opposite ends provide a quenched probe system useful for detecting PCR product and nucleic acid hybridization. PCR Methods Appl, 4(6): 357-362.

Lupiani B, Lee LF, Cui XP, Gimeno I, Anderson A, Morgan RW, Silva RF, Witter RL, Kung HJ, Reddy SM. 2004. Marek's disease virus-encoded meq gene is involved in transformation of lymphocytes but is dispensable for replication. Proc Natl Acad Sci, 101: 11815-11820.

Lupiani B, Williams SM, Silva RF, Hunt HD, Fadly AM. 2003. Pathogenicity of two recombinant avian leukosis viruses. Avian Dis, 47: 425-432.

Mitra N, Verma R, Amarjit S. 2012. Early Detection of Avian
Oncogenic Viruses from Blood of Apparently Healthy Chickens. Proc Natl Acad Sci, 83(1): 53-58.

Moelling K., Gelderblom H, Pauli G, Friis R. 1975. A comparative study of the avian reticuloendotheliosis virus: relationship tomurine leukemia virus and viruses of the avian sarcomaleukosis complex. Virology, 65(2): 546-57.

Morrison TB, Weis JJ, Wittwer CT. 1998. Quantification of lowcopy transcripts by continuous SYBR Green I monitoring during amplification. Biotechniques, 24(6): 954-958, 960, 962.

Morrow C, Fehler F. 2004. Marek's disease: a worldwide problem. In Marek's disease: an evolving problem, Edited by Davison F, Nair V. London: Elsevier Academic Press; 49-61.

Nair V. 2013. Latency and tumorigenesis in Marek's disease. Avian Dis, 57(2s1): 360-365.

Nair V, Fadly AM. 2013. Leukosis/Sarcoma Group, In Diseases of Poultry, 13th edition, Swayne, David E., Glisson, John R., McDougald, Larry R., Nolan, Lisa K., Suarez, David L. And Nair, Venugopal (editors)., p. 553-592.Wiley-Blackwell, Ames.

Nazarenko I. 2006. Homogeneous detection of nucleic acids using selfquenched polymerase chain reaction primers labeled with a single fluorophore (LUX primers). Methods Mol Biol, 335: 95-114.

Nazarenko IA, Bhatnagar SK, Hohman RJ, 1997. A closed tube format for amplification and detection of DNA based on energy transfer. Nucleic Acids Res, 25: 2516-2521.

Nazerian K, Solomon JJ, Witter RL, Burmester BR. 1968. Studies on the etiology of Marek's disease. II. Finding of a herpesvirus in cell culture. Proc Soc Exp Biol Med, 127: 177-182.

Niewiadomska AM, Gifford RJ. 2013. The extraordinary evolutionary history of the reticuloendotheliosis viruses. PLoS Biol, 11(8).

Nuovo GJ, Hohman RJ, Nardone GA, Nazarenko IA. 1999. In situ amplification using universal energy transfer-labeled primers, J Histochem Cytochem, 47: 273-280.

OECD. 2014. Meat consumption, Retrieved from http://www.oecd-ilibrary.org/content/ indicator/fa290fd0en.

Parcells MS, Lin SF, Dienglewicz RL, Majerciak V, Robinson DR, Chen HC, Wu Z, Dubyak GR, Brunovskis P, Hunt HD, Lee LF, Kung HJ. 2001. Marek's disease virus (MDV) encodes an interleukin-8 homolog (vIL-8): Characterization of the vIL-8 protein and a vIL-8 deletion mutant MDV. J Virol, 75: 51595173.

Payne LN, Brown SR, Bumstead N, Howes K, Frazier JA, Thouless ME. 1991. A novel subgroup of exogenous avian leukosis virus in chickens. J Gen Virol, 72(4): 801-807.

Payne LN, Howes K, Gillespie AM, Smith LM. 1992. Host range of Rous sarcoma virus pseudotype RSV(HPRS-103) in 12 avian species: support for a new avian retrovirus envelope subgroup, designated. J Gen Virol, 73(11): 2995-2997.

Payne LN, Fadly AM. 1997. Leukosis/sarcoma group. Diseases of Poultry, 10th Ed., pp. 414-466. Iowa State University Press, Ames, Iowa.

Payne LN, Venugopal K. 2000. Neoplastic diseases: Marek's disease, avian leukosis and reticuloendotheliosis. Rev Sci Tech Off Int Cpiz, 19(2): 544-564.

Persson K, Hamby K, Ugozzoli LA, 2005. Four-color multiplex reverse transcription polymerase chain reaction-overcoming its limitations. Anal Biochem, 344: 33-42.

Purchase HG, Ludford C, Nazerian K, Cox HW. 1973. A new group of oncogenic viruses: Reticuloendotheliosis, chick syncytial, duck infectious anemia, and spleen necrosis viruses. J Natl Cancer Inst, 51(2): 489-499.

Puro KU, Bhattacharjee U, Baruah S, Sen A, Das S, Ghatak S, Doley 
SR. Shakuntala I. 2018. Characterization of Marek's disease virus and phylogenetic analyses of meq gene from an outbreak in poultry in Meghalaya of Northeast India. VirusDisease, 29(2): 167-172.

Reddy SM, Lupiani B, Gimeno IM, Silva RF, Lee LF, Witter RL. 2002. Rescue of a pathogenic marek's disease virus with overlapping cosmid dnas: Use of a pp38 mutant to validate the technology for the study of gene function. Proc Natl Acad Sci, 99: 7054-7059.

Roberts L. 2000. Human genome research-SNP mappers confront reality and find it daunting. Science, 287(5460): 1898-1899.

Schweiger B, Zadow I, Heckler R, Timm H, Pauli G. 2000. Application of a fluorogenic PCR assay for typing and subtyping of influenza viruses in respiratory samples. J Clin Microbiol, 38 (4): 1552-1558.

Selvin PR, Hearst JE. 1994. Luminescence energy transfer using a terbium chelate: improvements on fluorescence energy transfer. Proc Natl Acad Sci, 91(21): 10024-10028.

Silva RF, Fadly AM, Taylor SP. 2007. Development of a polymerase chain reaction to differentiate avian leukosis virus (ALV) subgroups: detection of an ALV contaminant in commercial Marek's disease vaccines. Avian Dis, 51(3): $663-$ 667.

Smith RE. 1982. Avian osteopetrosis. Curr Top Microbiol Immunol, 101: 75-94.

Strassheim S, Stik G, Rasschaert D, Laurent S. 2012. mdv1-mir$m 7-5 p$, located in the newly identified first intron of the latency-associated transcript of Marek's disease virus, targets the immediate-early genes ICP4 and ICP27. J Gen Virol, 93: 1731-1742.

Sun GR, Zhang YP, Zhou LY, Lv HC, Zhang F, Li K, Gao YL, Qi XL, Cui HY, Wang YQ, Gao L, Pan Q, Wang XM, Liu CJ. 2017. CoInfection with Marek's Disease Virus and Reticuloendotheliosis Virus Increases Illness Severity and Reduces Marek's Disease Vaccine Efficacy. Viruses, 9(6):158.

Thelwell N, Millington S, Solinas A, Booth J, Brown T. 2000. Mode of action and application of Scorpion primers to mutation detection. Nucleic Acids Res, 28(19): 3752-3761.

Tsai WP, Copeland TD, Oroszlan S. 1985. Purification and chemical and immunological characterization of avian reticuloendotheliosis virus gag-gene-encoded structural proteins. Virology, 140(2): 289-312.

Tsai WP, Copeland TD, Oroszlan S. 1986. Biosynthesis and chemical and immunological characterization of avian reticuloendotheliosis virus env gene-encoded proteins. Virology, 155(2): 567-83.

Tseng SY, Macool D, Elliott V, Tice G, Jackson R, Barbour M, Amorese D. 1997. An homogeneous fluorescence polymerase chain reaction assay to identify Salmonella. Anal Biochem, 245(2): 207- 212.

Tyagi S, Bratu DP, Kramer FR. 1998. Multicolor molecular beacons for allele discrimination. Nat Biotechnol, 16(1): 4953.

Tyagi S, Kramer FR. 1996. Molecular beacons: probes that fluoresce upon hybridization. Nat Biotechnol, 14(3): 303-308.
Vet JA, Van der Rijt BJ, Blom HJ. 2002. Molecular beacons: colorful analysis of nucleic acids. Expert Rev Mol Diagn, 2(1): 77-86.

Walkden-Brown S, Islam A, Groves P, Rubite A, Sharpe SM, Burgess S. 2013a. Development, application, and results of routine monitoring of Marek's disease virus in broiler house dust using real-time quantitative PCR. Avian Dis, 57: 544-554.

Walkden-Brown S, Islam A, Islam AF, Burgess SK, Groves PJ, Cooke J. 2013b. Pathotyping of Australian isolates of Marek's disease virus in commercial broiler chickens vaccinated with herpesvirus of turkeys (HVT) or bivalent (HVT/SB1) vaccine and association with viral load in the spleen and feather dander. Aust Vet J, 91: 341-350.

Walker MH, Rup BJ, Rubin AS, Bose HR. 1983. Specificity in the immunosuppression induced by avian reticuloendotheliosis virus. Infect Immun, 40(1): 225-235.

Wang LC, Huang D, Pu CE, Wang CH. 2014. Avian oncogenic virus differential diagnosis in chickens using oligonucleotide microarray. J Virol Methods, 210: 45-50.

Wei K, Sun Z, Zhu S, Guo W, Sheng P, Wang Z, Zhao C, Zhao Q, Zhu R. 2012. Probable congenital transmission of reticuloendotheliosis virus caused by vaccination with contaminated vaccines. PLoS ONE, 7: e43422.

Whitcombe D, Theaker J, Guy SP, Brown T, Little S. 1999. Detection of PCR products using self-probing amplicons and fluorescence. Nat Biotechnol, 17(8): 804-807.

Witter RL, Fadly AM. 2003. Reticuloendotheliosis, Diseases of poultry. Ames, IA: Iowa State University Press; p. 517-535.

Witter RL, Peterson IL, Smith EJ, Johnson DC. 1982. Serologic evidence in commercial chicken and turkey flocks of infection with reticuloendotheliosis virus. Avian Dis, 26(4): 753-762.

Wittwer CT, Herrmann MG, Moss AA, Rasmussen RP. 1997a. Continuous fluorescence monitoring of rapid cycle DNA amplification. Biotechniques, 22(1): 130-131.

Wittwer CT, Ririe KM, Andrew RV, David DA, Gundry RA, Balis UJ. 1997b. The Light Cycler: a micro volume multi-sample fluorimeter with rapid temperature control, Biotechniques, 22 (1), 176-181.

Wu P, Brand L. 1994. Resonance energy transfer: methods and applications. Anal Biochem, 218(1): 1-13.

Yang L, Shuai C, Cui Z, Shuang C, Peng Z. 2016. Genome analysis and pathogenicity of reticuloendotheliosis virus isolated from a contaminated vaccine seed against infectious bursal disease virus, first report in China. J Gen Virol, 97: 2809-2815.

Zeng T, Xie Z, Xie L, Deng X, Xie Z, Luo S, Huang L, Huang J. 2015. Simultaneous detection of eight immunosuppressive chicken viruses using a GeXP analyser-based multiplex PCR assay. Virol J, 12: 226.

Zhang X, Liao M, Jiao P, Luo K, Zhang H, Ren T, Zhang G, Xu C, Xin C, Cao W. 2010. Development of a loop-mediated isothermal amplification assay for rapid detection of subgroup J avian leukosis virus. J Clin Microbiol, 48: 2116-2121.

Zhang YP, Lv HC, Bao KY, Gao YL, Gao HL, le Qi X, Cui HY, Wang YQ, Li K, Gao L, Wang XM, Liu CJ. 2016. Molecular and pathogenicity characterization of gallid herpesvirus 2 newly isolated in China from 2009 to 2013. Virus Genes, 52: 51-60. 